\title{
PI3K Signaling in Neurons: A Central Node for the Control of Multiple Functions
}

\author{
Karina Sánchez-Alegría ${ }^{\dagger}$, Manuel Flores-León ${ }^{\dagger}$, Evangelina Avila-Muñoz, \\ Nelly Rodríguez-Corona and Clorinda Arias *iD \\ Departamento de Medicina Genómica y Toxicología Ambiental, Instituto de Investigaciones Biomédicas, \\ Universidad Nacional Autónoma de México, AP 70-228, 04510 México, DF, Mexico; \\ k.aisa.62@hotmail.com (K.S.-A.); manuel.leoncio75@gmail.com (M.F.-L.); avmueva@gmail.com (E.A.-M.); \\ rodriguezcorona.nelly@gmail.com (N.R.-C.) \\ * Correspondence: carias@unam.mx; Tel.: +52-55-5622-9215; Fax: +52-55-5622-9182 \\ + These two authors contributed equally to this work.
}

Received: 19 October 2018; Accepted: 15 November 2018; Published: 23 November 2018

\begin{abstract}
Phosphoinositide 3-kinase (PI3K) signaling contributes to a variety of processes, mediating many aspects of cellular function, including nutrient uptake, anabolic reactions, cell growth, proliferation, and survival. Less is known regarding its critical role in neuronal physiology, neuronal metabolism, tissue homeostasis, and the control of gene expression in the central nervous system in healthy and diseased states. The aim of the present work is to review cumulative evidence regarding the participation of PI3K pathways in neuronal function, focusing on their role in neuronal metabolism and transcriptional regulation of genes involved in neuronal maintenance and plasticity or on the expression of pathological hallmarks associated with neurodegeneration.
\end{abstract}

Keywords: PI3K signaling; neurodegeneration; neuronal metabolism; gene expression; neuroinflammation

\section{Introduction}

Phosphoinositide 3-kinases (PI3Ks) are a family of multifaceted enzymes that play a central role in diverse metabolic processes that regulate many aspects of cell physiology. PI3Ks are evolutionarily conserved enzymes that transduce mitogenic and metabolic signals to promote cell growth, proliferation, migration, and apoptosis [1-3]. PI3Ks belong to a family of lipid kinases that comprise eight isoforms that have been classified according to their substrate specificity and structural features into three classes: I, II, and III [1-4]. The most studied family is class I, which catalyzes the conversion of phosphatidylinositol into 3'-phosphoinositides (PtdIns-3P), while class II PI3Ks, which consist of a single catalytic subunit, prefer PtdIns-4P and PtdIns-3,4P as substrates, similar to class III PI3Ks, which are additionally involved in vesicular trafficking, secretion, and autophagy [5-7].

Class I PI3Ks form a functional heterodimer composed of two subunits, one catalytic and one regulatory, with molecular weights of $110 \mathrm{kDa}(\mathrm{p} 110)$ and $85 \mathrm{kDa}(\mathrm{p} 85)$, respectively. The catalytic p110 subunit also has four different isoforms $(\alpha, \beta, \gamma$, and $\delta$, also known as PI3KCA, PI3KCB, PI3KCG, and PI3KCD, respectively), and the most frequent regulatory p 85 subunit encoded by three different genes $(\alpha, \beta$, and $\gamma)$ [8]. Most neurons in the hippocampus, cerebral cortex, and cerebellum express both the catalytic p110 $\alpha$ and all the regulatory p85 subunits at high levels $[9,10]$. PI3K activates protein kinase $\mathrm{B}(\mathrm{PKB})$, also known as AKT, which in turn activates mTOR. Particularly in the brain regions aforementioned, activation of the AKT/mTOR pathway seems to be essential for neuronal development and synapse formation [11-14] and contributes to neuronal plasticity and memory performance [15-18]. The activation of this pathway through receptor tyrosine kinase (RTK) by growth factors constitute the core path that regulates neuronal proliferation, maturation, and integration 
into mature circuits in the brain [19]. The important function of PI3K in neurons has also been demonstrated for its involvement in severe brain pathologies, such as developmentally-associated brain malformations [20,21], epilepsy [22,23], aging-associated neurodegeneration [24-26], and brain cancer $[27,28]$.

Different combinations of PI3K isoforms may result in different functional events depending on the metabolic context, upstream signals, and interconnection of different cellular pathways. For example, in sensory neurons, p110 $\delta$ is an important signaling component for efficient axonal elongation in the developing and regenerating nervous system [29]. In this sense, the inactivation of the p1108 produces deficient axonal elongation and prevents axonal regeneration in a model of sciatic nerve crush injury [29]. The manipulation of PI3K/AKT signaling has been proven to induce dramatic changes in myelination. In a conditional knockout for PTEN, the phosphatase that reduces the activation of PI3K/AKT, a hypermyelination phenotype is associated with an increase in PtdIns-3P and AKT activation [30]. It has also been confirmed that the increased synthesis of the p110 $\beta$ subunit of PI3K contributes to the anatomical, behavioral, and molecular defects associated with fragile $X$ syndrome [31]. Accordingly, many studies have demonstrated that the activation of PI3K induces cell proliferation, and overexpression of the p85 regulatory subunit inhibits PI3K/AKT signals, impairs neuronal stem cell proliferation, and disturbs neuronal differentiation during the development of mouse cerebral cortex [32]. PI3K dysregulation also plays a significant role in glioblastoma pathogenesis. Pharmacological inhibition of the catalytic subunits $\mathrm{p} 110 \beta$ and $\mathrm{p} 110 \alpha$ but not $\mathrm{p} 110 \delta$ has impaired glioblastoma growth and caused tumor regression in in vivo models [33]. On the other hand, increased PI3K/AKT/mTOR signaling was identified in several human brain samples, strongly implicating this pathway in diverse cases of hemimegaloencephaly, a developmental disorder characterized by brain overgrowth dependent on the increased number of neurons and glial cells [34].

All of these studies indicate that PI3K/AKT is a central node that integrates developmental signals that are necessary for brain development, maintenance, repair, and plasticity during adult life.

\section{PI3K Signaling in Neuronal Metabolism}

PI3K signaling associated with metabolism has been mainly in the hypothalamus, a region that regulates energy balance and glucose homeostasis. Clear implications point to the role of class I PI3K in energy balance in hypothalamic neurons. PI3K/AKT activation by insulin inhibits glucose production in the liver through the activation of ATP-dependent $\mathrm{K}^{+}$channels in the hypothalamus [35-38]. In fact, the infusion of insulin and the consequent activation of the PI3K pathway is able to suppress glucose production independently of circulating insulin. Recently, it has been shown that different PI3K catalytic subunits are involved in differential responses of hypothalamic neurons by insulin or leptin. For example, while neuronal hyperpolarization induced by insulin and leptin depends on both $\mathrm{p} 110 \alpha$ and $\mathrm{p} 110 \beta$ PI3K catalytic subunits, the depolarization effect of leptin depends solely upon the PI3K $110 \beta$ subunit [39]. These differences affect the regulation of energy balance and glucose homeostasis. PI3K/AKT pathway also contributes to glucose uptake and energy metabolism through the regulation of GLUT3 transporter expression, as well as the expression of the glycolytic enzyme phosphofructokinase-1 (PFK-1) during differentiation of cortical neurons [40]. It has been shown that neuronal glucose uptake is not dependent upon insulin/PI3K/AKT signaling; however, after high neuronal activity, the insulin/PI3K/AKT pathway induces GLUT4 translocation to the membrane to increase glucose transport in hippocampal neurons and improve cognitive functioning [41]. Accordingly, insulin administration improves memory task performance. This positive effect on cognition is completely mediated by PI3K activation and the increase in local glucose metabolism [42]. Thus, the insulin/PI3K/AKT/mTOR pathway importantly modulates neuronal plasticity underlying high cognitive functions. In fact, it was recently reported that AKT3 knockout mice exhibit microcephaly, cognitive defects, and reduced protein synthesis in response to long-term potentiation (LTP) via inactivation of mTOR and reduced protein synthesis necessary to sustain plasticity changes [43]. Different isoforms of PI3K have been implicated in 
synaptic plasticity and cognitive functions. Genetic deletion or overexpression of PI3K $\gamma$ disrupts long-term depression (LTD) and reduces spatial learning tasks, while contextual fear memory is not affected $[44,45]$. Similarly, activation of PI3K in the amygdala was found to be associated with fear conditioning [46].

Dysregulated PI3K/AKT signaling in neurons has several harmful consequences, such as elevated ROS levels, membrane depolarization, mitochondrial fragmentation, and decreased oxidative phosphorylation and ATP production [47-50]. It is particularly interesting that the amyloid peptide involved in Alzheimer's disease (AD) is capable of producing sustained activation of AKT, which in turn phosphorylates the mitochondrial fission protein Drp1. This mechanism has been proposed to be involved in the mitochondrial fragmentation observed in this neurodegenerative disease [47-50] (Figure 1).

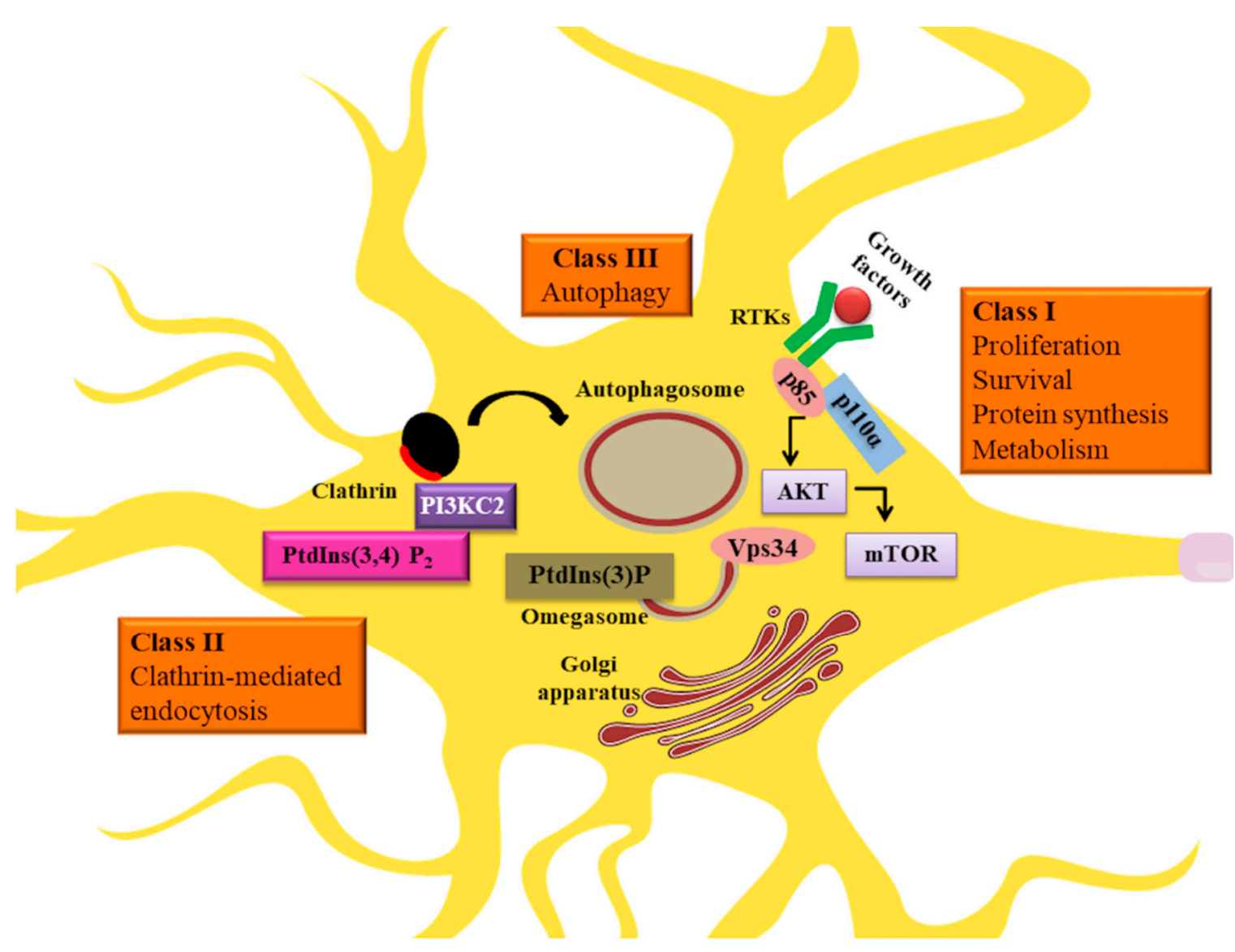

Figure 1. Involvement of different phosphoinositide 3-kinase (PI3K) classes in neuronal function. Class I acting through receptor tyrosine kinase (RTK) pathways mediate survival, proliferation, protein synthesis, and metabolism. Class II participates in vesicular trafficking and class III in autophagy.

\section{The Role of PI3K in Neuroinflammation}

Inflammation is recognized as a central player in a variety of brain diseases. An exacerbated inflammatory response has been associated with some chronic neuropathological conditions, such as $\mathrm{AD}$ [51-56]. There is evidence at the systemic level that PI3K induces the activation of NF- $\mathrm{KB}$ and, specifically, class I PI3Ks are involved in the transduction pathway of toll-like receptors (TLRs) in immune cells, such as macrophages and dendritic cells. However, in regard to the role of activation of different isoforms of the class I PI3Ks, the results have suggested that they can play either positive or negative roles in the production of pro-inflammatory cytokines [57]. It has been shown that the activation of TLRs can induce the recruitment of class I $\alpha$ PI3Ks, which leads to downregulation in NF-kB-induced pro-inflammatory cytokines in macrophages [57]. On the other hand, loss of functional 
PI3K $\delta$ reduces TLR4 internalization and relocation to endosomes, promoting the early secretion of pro-inflammatory cytokines (IL-6 and IL-12) and reducing the secretion of anti-inflammatory cytokines such as interleukin-10 (IL-10) and interferon- $\beta$ (IFN- $\beta$ ) in dendritic cells [58]. Additionally, it has been shown in vitro and in vivo that $\mathrm{PI} 3 \mathrm{~K} \gamma$ plays an important role in the initial signal transduction events downstream of chemoattractant and chemokine G protein-coupled receptors (receptors for fMLP, C5a, IL-8, LTB4) that promote the extravasation and migration of innate immune cells, such as neutrophils, monocytes, or eosinophil, during inflammation [51,59-66].

In the central nervous system (CNS), microglial cells are resident macrophages involved in immunological responses. Excessive microglia activation may lead to synaptic loss and neuronal dysfunction. It has been shown that the activation of AKT precedes NF-KB-dependent transcription of proinflammatory genes in activated microglia. In this report, the authors found that LPS is able to activate PI3K/AKT through the stimulation of TLR4 [67]. Moreover, using different natural compounds, it has been suggested that PI3Ks are involved in the development of the neuroinflammatory response modulating the release of cytokines. For example, studies in LPS-stimulated microglial cells demonstrated that curcumin attenuates the expression of TNF- $\alpha$, IL-6, and IL-1 $\beta$ through the suppression of PI3K/AKT-mediated activities $[68,69]$. Additionally, the flavonoid compound morin exerts anti-inflammatory effects by downregulating MAPK and PI3K/AKT signaling pathways and upregulating the anti-inflammatory PKA/CREB and Nrf2/HO-1 pathways in microglia [70]. Furthermore, it has been shown that TGF-1 $\beta$, an anti-inflammatory molecule, protects brain tissue by repressing the overactivation of microglial cells via inhibition of PI3K and its downstream signaling molecules [71]. Remarkably, not only are glial cells involved in neuroinflammation, but hippocampal neurons can also contribute to neuroinflammation by releasing TNF- $\alpha$ and IL-1 $\beta$ via TLR4-mediated PI3K/AKT/NF-KB signaling [72].

Chronic inflammation in the brain is a feature of some neurological disorders associated with neuronal damage. Therefore, pharmacological-based therapies focusing on PI3K signaling is a promising research avenue. For example, in an injury model of cerebral ischemia/reperfusion, the use of a class I PI3K inhibitor (ZSTK474) was able to alleviate neurological deficits and reduce the infarct volume. This therapeutic benefit was associated with the induction of an anti-inflammatory phenotype in microglia leading to a decrease in secreted pro-inflammatory molecules through the $\mathrm{PI3K} / \mathrm{AKT} / \mathrm{mTORC1}$ pathway [73].

In another model of brain injury due to a surgical procedure (SBI), it has been demonstrated that $\mathrm{PI} 3 \mathrm{~K} \gamma$ promotes a pro-inflammatory phenotype. Furthermore, pharmacological inhibitors of PI3K $\gamma$ (AS252424 or AS605240) improve neurological function after SBI [74]. Interestingly, chronic neuroinflammation has been associated with the development of AD [53-56] and a variety of inflammatory intermediaries, including IL- $1 \beta$, IL- 6 , and TNF- $\alpha$, have been found to be upregulated in this disease $[51,52,54,55]$. Epidemiological studies indicate that anti-inflammatory agents, such as non-steroidal anti-inflammatory drugs (NSAIDs), have a beneficial effect on AD, and several reports have shown that NSAIDs protect against inflammation in transgenic AD models [56]. It has been shown that some NSAIDs can exert their actions by modulating PI3K [75-77]. Thus, an interesting line of investigation is now directed at analyzing the relationship between inflammation, PI3K signaling, and AD.

\section{Genetic and Epigenetic Regulation through the PI3K/AKT Signaling Pathway}

One of the main processes that control the genetic programming and functions of neurons is the recruitment and activation of transcription factors and chromatin remodeling complexes in response to specific intrinsic demands and upstream signals. PI3K, through AKT activation, enhances the interaction and activity of several transcription complexes composed of basic helix-loop-helix (bHLH) transcription factors (Neurogenin, NeuroD1, and MASH1), acetyltransferases (HATs), such as CBP and p300, and histone deacetylases (HDACs) [78]. 
In vitro experiments demonstrate that $\mathrm{AKT}$ activation by the natural flavonoid curcumin in combination with an inhibitor of HDACs improves neuronal survival and restores neuronal damage induced by amyloid beta $(\mathrm{A} \beta)$, which is a peptide associated with $\mathrm{AD}$ [79]. One of the proposed mechanisms for such protection is the AKT-dependent phosphorylation of the transcription factor CREB, which in turn promotes the expression of the brain-derived neurotrophic factor gene $b d n f$. Neuronal survival also seems to be dependent on PI3K/AKT signaling through regulation of the NF- $\mathrm{KB}$ transcription factor at two levels: through enhancing the activity of the inhibitory kinase IKK and by directly phosphorylating NF- $\mathrm{kB}$, which increases its activity [80,81].

Experiments in PC12 cells strongly suggest that PI3K/AKT is the signaling pathway responsible for the activation of late phase gene expression involved in neuronal differentiation, neurogenesis, and neuroprotection [82]. Interestingly, nerve growth factor (NGF)-dependent PI3K/AKT/NF-KB signaling is also associated with an epigenetic modification at lysine 9 of histone 3 (H3K9) during neuronal differentiation through the expression of the $G$ protein-coupled delta opioid receptor gene dor [83].

Forkhead transcription factors (FOXO) are a family of proteins that play important roles in regulating the expression of genes involved in cell growth, apoptosis, and longevity. When AKT phosphorylates FOXO, it is translocated from the nucleus to the cytosol as an inactive complex, inhibiting transcription of the tumor suppressor p53 and preventing apoptosis, as previously demonstrated in hippocampal neurons after hypoxia [84]. Interestingly, PI3K/AKT signaling is inhibited in neuronal cultures exposed to the $\mathrm{A} \beta$ peptide, which induces the translocation of FOXO from the cytosol to the nucleus and the expression of the proapoptotic protein BIM [85]. Recent results have suggested that the neuroprotective effect of the mood stabilizer valproic acid is mediated through the inhibition of glycogen synthase kinase-3 (GSK3) and the activation of PI3K/AKT signaling. Valproic acid is one of the best known epi-drugs and acts as a pan-inhibitor of HDACs that are associated with chromatin remodeling and transcriptional activation of neuroprotective genes, such as fibroblast growth factor (FGF-21) mRNA [86].

The balance between acetylation and deacetylation is crucial for the regulation of gene expression in physiological and pathological conditions. Both epigenetic processes are altered during aging and in some neuropathological conditions, such as AD. Studies in primary neuronal cultures and in vivo mouse models of $\mathrm{AD}$ at different stages have revealed increased global levels of acetylated histones $\mathrm{H} 3$ and $\mathrm{H} 4$ [87]. The hyperacetylated state of $\mathrm{H} 3$ and $\mathrm{H} 4$ was also observed in post-mortem brains of $\mathrm{AD}$ patients, especially in the most affected regions, such as the inferior and middle temporal gyrus [88]. Since acetylated histones are associated with open states of the chromatin that allow gene transcription, several genes that play an important role in the progression of AD markers can be upregulated when chromatin is hyperacetylated. One of these genes is the Bace1 gene for the $\beta$-site amyloid precursor protein-cleaving enzyme 1 (BACE1). Upregulation of BACE1 mRNA associated with hyperacetylation in the promoter region of Bace1 has been reported in the 3xTg-AD mouse model [89,90]. Furthermore, in vitro experiments have demonstrated that this hyperacetylation is associated with a hyperactivated state of the acetyltransferase p300 that not only modifies histones but can recruit transcription factors such as CREB and NF-kB [90].

In addition to acetylation, histones can be mono-, di-, or trimethylated on lysine or arginine residues. However, less is known about how PI3K/AKT can regulate these posttranslational modifications. It has been shown that the polycomb repressive complex 2 is responsible for establishing this epigenetic mark through the methyltransferase enhancer Zeste 2 (EZH2). EZH2 can be regulated by AKT phosphorylation, which reduces its activity and, therefore, the amount of H3K27me3 in the genome [91]. Interestingly, the reduction of this epigenetic marker is associated with the activation of several genes involved in memory, cognition, cell survival, and axonal growth [91,92]. 
Because epigenetic mechanisms are dynamic and constantly changing, it is not surprising that PI3K/AKT signaling activation in response to growth factors can modulate some of the eraser proteins, such as histone demethylases (KDMs). The phosphorylation induced by AKT promotes the exit of KDM5A from the nucleus and the increase in H3K4me3 content associated with active transcription in specific promoters [91]. Interestingly, it has been shown that brains affected by AD aberrantly accumulate H3K4me3 in the neuronal cytoplasm. This accumulation is associated with the progression of AD-related pathological hallmarks, making a positive correlation as the pathology worsens [93]. These studies suggest that the role of PI3K/AKT participation in AD modifies the transcription of genes related to neuronal function and survival through changes in epigenetic markers.

DNA methyltransferases (DNMTs) are enzymes that are responsible for the addition of a methyl group to the $\mathrm{C} 5$ cytosine residue to produce 5-methylcytosine (5mC). During the development of neural stem cells (NSCs), inhibition of the PI3K/AKT signaling pathway enhances the expression of DNMT1 and DNMT3a and turns off the transcription of genes in a concerted manner through differentiation and maturation processes [94]. PI3K/AKT signaling also induces upregulation of the activity of the TET enzymes producing active DNA demethylation. This activation allows differentiation genes, such as the Ngn1, to be activated and promotes neuronal stem cell (NSC) commitment to the neural lineage [94].

The regulation of DNA methylation and demethylation processes needs to be tightly controlled through adulthood. Recent studies in the AD model 5xFAD report that DNA methylation is increased when $A \beta$ begins to accumulate and this increase is accompanied by the upregulation of DNMTs [95]. Nevertheless, it is not surprising that different studies report different findings when analyzing post-mortem brains of patients diagnosed with $\mathrm{AD}$. One of the first groups that studied these markers in human brains reported a global decrease in $5 \mathrm{mC}$ and $5 \mathrm{hmC}$ in the hippocampus, particularly in the CA1 region and the dentate gyrus [96]. However, another study reported hypermethylation of autosomal differentially methylated regions that also contained altered histone methylation markers [97]. More specifically, the promoters of genes associated with plasticity, such as BDNF, have been found to have high levels of methylation in patients with $\mathrm{AD}$, which also correlates with a reduction in the mRNA or protein levels of BDNF [98]. The authors of the respective manuscripts discuss that the differences in their findings might be due to the nature of either the genetic background of the transgenic mice or the stage of $\mathrm{AD}$ in patients upon death. They further discuss that, at least in transgenic mice, when they compared aged mice to young mice, they found that the levels of epigenetic markers are upregulated. Nevertheless, the findings demonstrate that the regulation of the methylation/demethylation of DNA is affected by aging and AD. Another possibility to be considered is the particular state of PI3K/AKT activation and the levels of growth factors that are able to activate this signaling pathway.

Altogether, this evidence points to the important role of PI3K/AKT signaling in the regulation of gene transcription in the brain throughout life in healthy and diseased states. Although this pathway does not directly impact chromatin, it regulates several transcription factors and chromatin remodeling proteins and complexes that can alter the balance between heterochromatin and euchromatin. Furthermore, whenever this signaling pathway is altered, as in aging or AD, aberrant epigenetic signatures appear that deregulate gene expression, which eventually leads to neurodegeneration (Figure 2). 


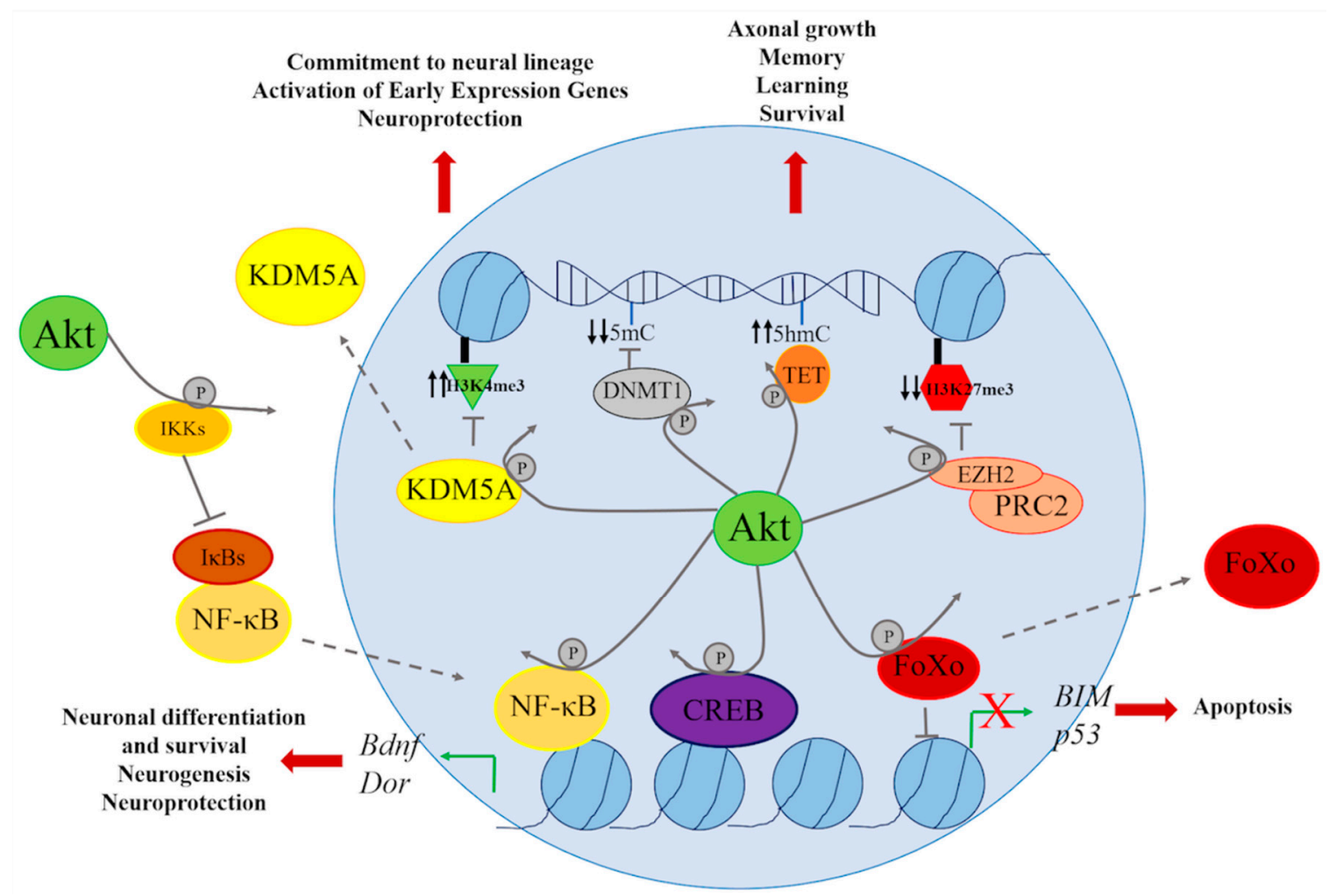

Figure 2. AKT phosphorylates several transcription factors, including NF- $\mathrm{B}, \mathrm{CREB}$, and FOXO, implicated in the transcription of genes regulating neuronal differentiation, neuroprotection, neurogenesis, and apoptosis, such as Bdnf, Dor, BIM, and p53. PI3K stimulation can also inhibit (KDM5A, DNMT1, and EHZ2) or activate (TET) chromatin-associated proteins leading to upregulation or repression of genes implicated in neural differentiation, axonal growth, memory, and learning through altering chromatin marks in histone tails of DNA modifications.

\section{Vesicle Recycling and Neurotransmission}

In addition to the significant role of class I PI3Ks in the brain and the vast knowledge around this family of PI3K, less is known about the important role of the class II and class III PI3Ks. The action of the two class II PI3Ks (PI3K-C2 $\alpha, \beta$ ) has been implicated in clathrin-mediated endocytosis, glucose transport, insulin secretion, neurosecretory granule release, muscle contraction, and cell migration [99]. At present, there is no clear evidence that class II PI3Ks are involved in AKT activation, although PI3K-C2 $\beta$ becomes activated by some growth factors, such as epidermal growth factor (EGF) and platelet-derived growth factor (PDGF), associated with RTKs [100]. Class II and III PI3Ks catalyze the conversion of PtdIns to PtdIns3P, which is a major constituent of endosomal membranes. PtdIns3P is an intracellular second messenger and a hallmark of many signaling pathways controlling proliferation, growth, invasion, and vesicle trafficking [101]. Distinctively, vesicle trafficking encompasses communication between endosomal compartments, which can assist in signaling transduction and act as integrators and processors. Moreover, recycling and retrieval of soluble or membrane-embedded protein cargos from the endosome to the trans-Golgi network or the plasma membrane determine the concentration of important molecules at the cell surface. Therefore, fine regulation of endosomal protein sorting and trafficking must occur to maintain neuronal homeostasis, synapse formation [102], or avoidance of neurodegeneration $[103,104]$. Although the role of class II PI3Ks in endocytic vesicle recycling is relevant, there are few studies on how the function of class II PI3Ks may impact neurotransmission in the nervous system. PI3K-C2 $\alpha$ is present in clathrin-coated vesicles of isolated brains [105] and binds to clathrin-mediated vesicles, which locally produce phosphoinositide in growing clathrin-coated pits [106]. In PC12 cells, activation of PI3K-C2 $\alpha$ enhances the exocytosis of neurosecretory granules, whereas transfection of PC12 cells with 
a catalytically inactive PI3K-C2 $\alpha$ inhibits this process [107]. Remarkably, PI3KC $2 \alpha$ not only participates in the exocytosis of neurosecretory granules but also in the exocytosis of cargos transported from the trans-Golgi network, such as delta opioid receptor $(\delta \mathrm{R})$, which requires PI3KC2 $\alpha$ for surface trafficking. Inhibition of PI3Ks with wortmannin causes the retention of $\delta \mathrm{R}$ at the Golgi complex, as shown by immunofluorescence colocalization of TGN-38 (a trans-Golgi network marker) and (GFP)- $\delta$ R [108] (Figure 3). On the other hand, phosphoinositides generated by class II PI3K and class III PI3K in Drosophila are necessary for the rapid appearance and long-term maintenance of pre-synaptic homeostatic potentiation through the enhancement of presynaptic vesicle recycling in Drosophila [109]. The class II PI3K homologous gene mutant disrupts the generation of PtdIns3P, which determines the early endosomal membrane required for the recruitment of Rab11 to recycling endosomes. Similarly, class III PI3K orthologue Vps34 and postsynaptic Rab11 knockdown also block the expression of trans-synaptic potentiation, demonstrating a new post-synaptic signaling depending on the formation of PtdIns3P by class II and III PI3Ks [109].

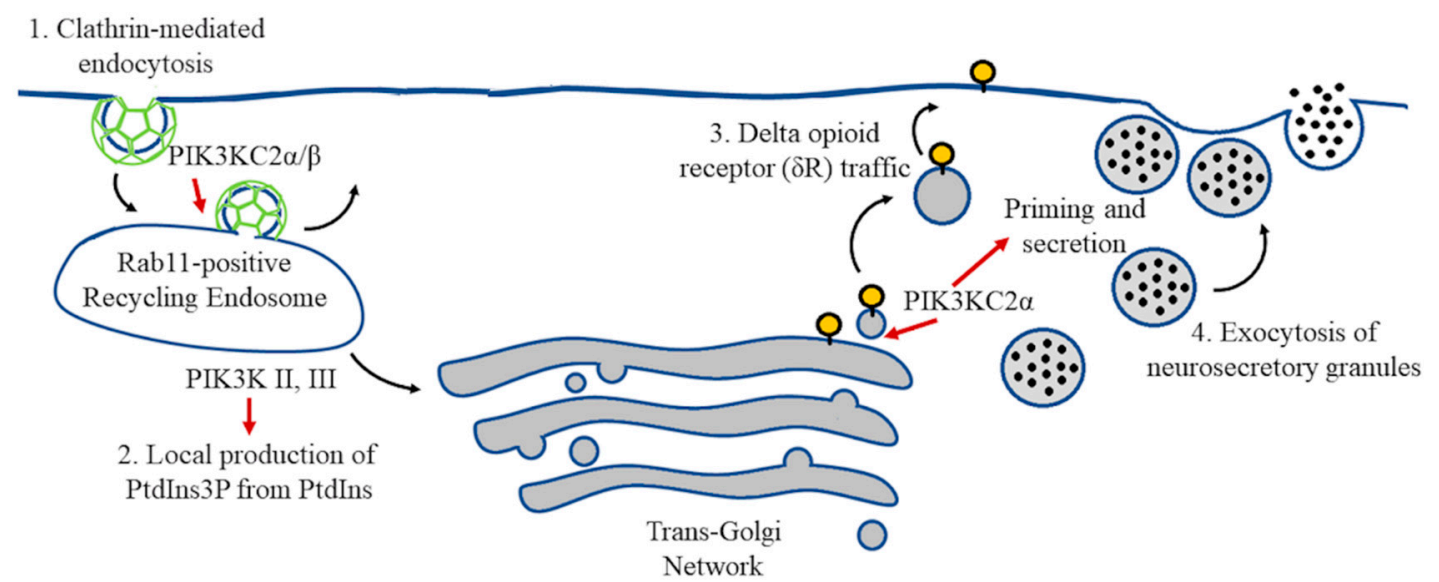

Figure 3. PIK3KC $2 \alpha$ and $\beta$ are associated with clathrin-coated endocytic intermediates (1.) while PIK3K II and III participate in the local production of PtdIns3P at recycling endosomes (2.). PI3KC2 $\alpha$ regulates priming and secretion of large dense core vesicles at chromaffin cells (3.) and PI3KC2 $\alpha$ is required for Delta opioid receptor $(\delta \mathrm{R})$ trafficking [4].

\section{Class III PI3Ks in Neuronal Autophagy}

The class III PI3Ks mainly control the trafficking of intracellular vesicles in the context of autophagy, endocytosis, and phagocytosis. The Beclin 1-Vps34 complex is a core component of class III PI3Ks, and binds Atg14L or UVRAG to control different steps of autophagy in mammalian cells. It is not clear which extracellular stimuli are able to activate this complex although some evidence points to the role of nutrients such as glucose and amino acids [110]. The Beclin 1-Vps34 complex is essential for mouse development and viability [111]. Autophagy and endosomal processes are essential for maintaining neuronal stability [112,113]. In a recent study, it was reported that class III PI3K-deficient mice abnormally accumulate protein aggregates, vacuoles, and endosomes in large diameter sensory neurons and induce neurodegeneration [111]. Class III PI3K also mediates the endosome-lysosome degradation to promote axon pruning during development [114]. However, it must be mentioned that autophagy is a complex mechanism that also implicates regulation by $\mathrm{PI} 3 \mathrm{~K} / \mathrm{AKT} / \mathrm{mTOR}$ signaling.

\section{Conclusions}

PI3K-mediated signaling is a central node that coordinates a variety of complex events that lead to changes in neuronal development, growth, energy metabolism, and survival. All these functions are carried out through the integration of upstream signals and the downstream control of gene expression. The complexities of function require further studies to better understand the specific 
regulation of different PI3K enzymes in different metabolic contexts that may have implications in neuronal physiology in healthy and diseased states. These studies will allow for future advances in the understanding of how PI3K signaling is designed and implemented at the cellular and molecular levels to control basic neuronal processes, as well as for the therapeutic development of drugs targeting different PI3K isoforms for treating brain pathologies.

Author Contributions: C.A.: conceptualization and investigation and manuscript preparation; K.S.-A.: investigation and writing the PI3K and metabolism section; M.F.-L.: investigation and writing the PI3K and genetic control of gene expression section; E.A.-M.: investigation and writing the PI3K and inflammation section; and N.R.-C.: writing the class II and III Pi3K and neuronal function sections.

Funding: This research was funded by CONACyT 282470.

Conflicts of Interest: The authors declare no conflict of interest.

\section{References}

1. Engelman, J.A.; Luo, J.; Cantley, L.C. The evolution of phosphatidylinositol 3-kinases as regulators of growth and metabolism. Nat. Rev. Genet. 2006, 7, 606-619. [CrossRef] [PubMed]

2. Hawkins, P.T.; Anderson, K.E.; Davidson, K.; Stephens, L.R. Signalling through Class I PI3Ks in mammalian cells. Biochem. Soc. Trans. 2006, 34, 647-662. [CrossRef] [PubMed]

3. Hirsch, E.; Costa, C.; Ciraolo, E. Phosphoinositide 3-kinases as a common platform for multi-hormone signaling. J. Endocrinol. 2007, 194, 243-256. [CrossRef] [PubMed]

4. Jean, S.; Kiger, A.A. Classes of phosphoinositide 3-kinases at a glance. J. Cell Sci. 2014, 127, 923-928. [CrossRef] [PubMed]

5. Falasca, M.; Maffucci, T. Regulation and cellular functions of class II phosphoinositide 3-kinases. Biochem. J. 2012, 443, 587-601. [CrossRef] [PubMed]

6. Devereaux, K.; Dall'Armi, C.; Alcazar-Roman, A.; Ogasawara, Y.; Zhou, X.; Wang, F.; Yamamoto, A.; De Camilli, P.; Di Paolo, G. Regulation of Mammalian Autophagy by Class II and III PI 3-Kinases through PI3P Synthesis. PLoS ONE 2013, 8, e76405. [CrossRef] [PubMed]

7. Wang, Q.-W.; Wang, Y.; Wang, T.; Zhang, K.-B.; Jiang, C.-Y.; Hu, F.-F.; Yuan, Y.; Bian, J.C.; Liu, X.Z.; $\mathrm{Gu}$, J.H.; et al. Cadmium-induced autophagy promotes survival of rat cerebral cortical neurons by activating class III phosphoinositide 3-kinase/beclin-1/B-cell lymphoma 2 signaling pathways. Mol. Med. Rep. 2015, 12, 2912-2918. [CrossRef] [PubMed]

8. Van der Heide, L.P.; Ramakers, G.M.J.; Smidt, M.P. Insulin signaling in the central nervous system: Learning to survive. Prog. Neurobiol. 2006, 79, 205-221. [CrossRef] [PubMed]

9. Yu, J.; Zhang, Y.; McIlroy, J.; Rordorf-Nikolic, T.; Orr, G.A.; Backer, J.M. Regulation of the p85/p110 phosphatidylinositol 3'-kinase: Stabilization and inhibition of the p110alpha catalytic subunit by the p85 regulatory subunit. Mol. Cell Biol. 1998, 18, 1379-1387. [CrossRef] [PubMed]

10. Trejo, J.L.; Pons, S. Phosphatidylinositol-3-OH kinase regulatory subunits are differentially expressed during development of the rat cerebellum. J. Neurobiol. 2001, 47, 39-50. [CrossRef] [PubMed]

11. Jaworski, J.; Spangler, S.; Seeburg, D.P.; Hoogenraad, C.C.; Sheng, M. Control of Dendritic Arborization by the Phosphoinositide-3'-Kinase-Akt-Mammalian Target of Rapamycin Pathway. J. Neurosci. 2005, 25, 11300-11312. [CrossRef] [PubMed]

12. Chan, C.B.; Ye, K. Multiple Functions of Phosphoinositide-3 Kinase Enhancer (PIKE). Sci. World J. 2010, 10, 613-623. [CrossRef] [PubMed]

13. Cuesto, G.; Enriquez-Barreto, L.; Carames, C.; Cantarero, M.; Gasull, X.; Sandi, C.; Ferrús, A.; Acebes, Á.; Morales, M. Phosphoinositide-3-Kinase Activation Controls Synaptogenesis and Spinogenesis in Hippocampal Neurons. J. Neurosci. 2011, 31, 2721-2733. [CrossRef] [PubMed]

14. Akiyama, H.; Kamiguchi, H. Phosphatidylinositol 3-kinase facilitates microtubule-dependent membrane transport for neuronal growth cone guidance. J. Biol. Chem. 2010, 285, 41740-41748. [CrossRef] [PubMed]

15. Horwood, J.M.; Dufour, F.; Laroche, S.; Davis, S. Signalling mechanisms mediated by the phosphoinositide 3-kinase/Akt cascade in synaptic plasticity and memory in the rat. Eur. J. Neurosci. 2006, 23, 3375-3384. [CrossRef] [PubMed] 
16. Sui, L.; Wang, J.; Li, B.-M. Role of the phosphoinositide 3-kinase-Akt-mammalian target of the rapamycin signaling pathway in long-term potentiation and trace fear conditioning memory in rat medial prefrontal cortex. Learn. Mem. 2008, 15, 762-776. [CrossRef] [PubMed]

17. Bruel-Jungerman, E.; Veyrac, A.; Dufour, F.; Horwood, J.; Laroche, S.; Davis, S. Inhibition of PI3K-Akt signaling blocks exercise-mediated enhancement of adult neurogenesis and synaptic plasticity in the dentate gyrus. PLoS ONE 2009, 4, e7901. [CrossRef] [PubMed]

18. Kocsis, K.; Frank, R.; Szabó, J.; Knapp, L.; Kis, Z.; Farkas, T.; Vécsei, L.; Toldi, J. Acetyl-l-carnitine restores synaptic transmission and enhances the inducibility of stable LTP after oxygen-glucose deprivation. Neuroscience 2016, 332, 203-211. [CrossRef] [PubMed]

19. Waite, K.; Eickholt, B.J. The neurodevelopmental implications of PI3K signaling. Curr. Top. Microbiol. Immunol. 2010, 346, 245-265. [PubMed]

20. Rivière, J.-B.; Mirzaa, G.M.; O’Roak, B.J.; Beddaoui, M.; Alcantara, D.; Conway, R.L.; St-Onge, J.; Schwartzentruber, J.A.; Gripp, K.W.; Nikkel, S.M.; et al. De novo germline and postzygotic mutations in AKT3, PIK3R2 and PIK3CA cause a spectrum of related megalencephaly syndromes. Nat. Genet. 2012, 44, 934-940. [CrossRef] [PubMed]

21. Jansen, L.A.; Mirzaa, G.M.; Ishak, G.E.; O’Roak, B.J.; Hiatt, J.B.; Roden, W.H.; Gunter, S.A.; Christian, S.L.; Collins, S.; Adams, C.; et al. PI3K/AKT pathway mutations cause a spectrum of brain malformations from megalencephaly to focal cortical dysplasia. Brain 2015, 138, 1613-1628. [CrossRef] [PubMed]

22. Xiao, Z.; Peng, J.; Yang, L.; Kong, H.; Yin, F. Interleukin-1 $\beta$ plays a role in the pathogenesis of mesial temporal lobe epilepsy through the PI3K/Akt/mTOR signaling pathway in hippocampal neurons. J. Neuroimmunol. 2015, 282, 110-117. [CrossRef] [PubMed]

23. Brandt, C.; Hillmann, P.; Noack, A.; Römermann, K.; Öhler, L.A.; Rageot, D.; Beaufils, F.; Melone, A.; Sele, A.M.; Wymann, M.P.; et al. The novel, catalytic mTORC1/2 inhibitor PQR620 and the PI3K/mTORC1/2 inhibitor PQR530 effectively cross the blood-brain barrier and increase seizure threshold in a mouse model of chronic epilepsy. Neuropharmacology 2018, 140, 107-120. [CrossRef] [PubMed]

24. Heras-Sandoval, D.; Pérez-Rojas, J.M.; Hernández-Damián, J.; Pedraza-Chaverri, J. The role of $\mathrm{PI} 3 \mathrm{~K} / \mathrm{AKT} / \mathrm{mTOR}$ pathway in the modulation of autophagy and the clearance of protein aggregates in neurodegeneration. Cell Signal 2014, 26, 2694-2701. [CrossRef] [PubMed]

25. Yang, L.; Wang, H.; Liu, L.; Xie, A. The Role of Insulin/IGF-1/PI3K/Akt/GSK3 $\beta$ Signaling in Parkinson's Disease Dementia. Front. Neurosci. 2018, 12, 73. [CrossRef] [PubMed]

26. Ali, T.; Kim, T.; Rehman, S.U.; Khan, M.S.; Amin, F.U.; Khan, M.; Ikram, M.; Kim, M.O. Natural Dietary Supplementation of Anthocyanins via PI3K/Akt/Nrf2/HO-1 Pathways Mitigate Oxidative Stress, Neurodegeneration, and Memory Impairment in a Mouse Model of Alzheimer's Disease. Mol. Neurobiol. 2018, 55, 6076-6093. [CrossRef] [PubMed]

27. Li, S.; Chen, X.; Mao, L.; Zahid, K.R.; Wen, J.; Zhang, L.; Zhang, M.; Duan, J.; Duan, J.; Yin, X.; et al. Histone deacetylase 1 promotes glioblastoma cell proliferation and invasion via activation of PI3K/AKT and MEK/ERK signaling pathways. Brain Res. 2018, 1692, 154-162. [CrossRef] [PubMed]

28. Daniel, P.M.; Filiz, G.; Brown, D.V.; Christie, M.; Waring, P.M.; Zhang, Y.; Haynes, J.M.; Pouton, C.; Flanagan, D.; Vincan, E.; et al. PI3K activation in neural stem cells drives tumorigenesis which can be ameliorated by targeting the cAMP response element binding protein. Neuro Oncol. 2018, 20, 1344-1355. [CrossRef] [PubMed]

29. Eickholt, B.J.; Ahmed, A.I.; Davies, M.; Papakonstanti, E.A.; Pearce, W.; Starkey, M.L.; Bilancio, A.; Need, A.C.; Smith, A.J.H.; Hall, S.M.; et al. Control of Axonal Growth and Regeneration of Sensory Neurons by the p1108 PI 3-Kinase. PLoS ONE 2007, 2, e869. [CrossRef] [PubMed]

30. Gaesser, J.M.; Fyffe-Maricich, S.L. Intracellular signaling pathway regulation of myelination and remyelination in the CNS. Exp. Neurol. 2016, 283, 501-511. [CrossRef] [PubMed]

31. Gross, C.; Chang, C.-W.; Kelly, S.M.; Bhattacharya, A.; McBride, S.M.J.; Danielson, S.W.; Jiang, M.Q.; Chan, C.B.; Ye, K.; Gibson, J.R.; et al. Increased Expression of the PI3K Enhancer PIKE Mediates Deficits in Synaptic Plasticity and Behavior in Fragile X Syndrome. Cell Rep. 2015, 11, 727-736. [CrossRef] [PubMed]

32. Cheng, X.; Li, K.; Liu, M.; Xu, M.; Hu, X.; Yan, R.; Förster, E.; Zhao, S. The effect of P85 on neuronal proliferation and differentiation during development of mouse cerebral cortex. Dev. Biol. 2018, 441, 95-103. [CrossRef] [PubMed] 
33. Höland, K.; Boller, D.; Hagel, C.; Dolski, S.; Treszl, A.; Pardo, O.E.; Ćwiek, P.; Salm, F.; Leni, Z.; Shepherd, P.R.; et al. Targeting Class IA PI3K Isoforms Selectively Impairs Cell Growth, Survival, and Migration in Glioblastoma. PLoS ONE 2014, 9, e94132. [CrossRef] [PubMed]

34. Mirzaa, G.M.; Poduri, A. Megalencephaly and hemimegalencephaly: Breakthroughs in molecular etiology. Am. J. Med. Genet. Part C Semin. Med. Genet. 2014, 166, 156-172. [CrossRef] [PubMed]

35. Niswender, K.D.; Morrison, C.D.; Clegg, D.J.; Olson, R.; Baskin, D.G.; Myers, M.G., Jr.; Seeley, R.J.; Schwartz, M.W.; et al. Insulin activation of phosphatidylinositol 3-kinase in the hypothalamic arcuate nucleus: A key mediator of insulin-induced anorexia. Diabetes 2003, 52, 227-231. [CrossRef] [PubMed]

36. Obici, S.; Zhang, B.B.; Karkanias, G.; Rossetti, L. Hypothalamic insulin signaling is required for inhibition of glucose production. Nat. Med. 2002, 8, 1376-1382. [CrossRef] [PubMed]

37. Oh, H.; Boghossian, S.; York, D.A.; Park-York, M. The effect of high fat diet and saturated fatty acids on insulin signaling in the amygdala and hypothalamus of rats. Brain Res. 2013, 1537, 191-200. [CrossRef] [PubMed]

38. Pardini, A.W.; Nguyen, H.T.; Figlewicz, D.P.; Baskin, D.G.; Williams, D.L.; Kim, F.; Schwartz, M.W. Distribution of insulin receptor substrate-2 in brain areas involved in energy homeostasis. Brain Res. 2006, 1112, 169-178. [CrossRef] [PubMed]

39. Sohn, J.-W.; Oh, Y.; Kim, K.W.; Lee, S.; Williams, K.W.; Elmquist, J.K. Leptin and insulin engage specific PI3K subunits in hypothalamic SF1 neurons. Mol. Metab. 2016, 5, 669-679. [CrossRef] [PubMed]

40. Agostini, M.; Romeo, F.; Inoue, S.; Niklison-Chirou, M.V.; Elia, A.J.; Dinsdale, D.; Morone, N.; Knight, R.A.; Mak, T.W.; Melino, G. Metabolic reprogramming during neuronal differentiation. Cell Death Differ. 2016, 23, 1502-1514. [CrossRef] [PubMed]

41. Pearson-Leary, J.; Jahagirdar, V.; Sage, J.; McNay, E.C. Insulin modulates hippocampally-mediated spatial working memory via glucose transporter-4. Behav. Brain Res. 2018, 338, 32-39. [CrossRef] [PubMed]

42. McNay, E.C.; Ong, C.T.; McCrimmon, R.J.; Cresswell, J.; Bogan, J.S.; Sherwin, R.S. Hippocampal memory processes are modulated by insulin and high-fat-induced insulin resistance. Neurobiol. Learn. Mem. 2010, 93, 546-553. [CrossRef] [PubMed]

43. Zhang, T.; Shi, Z.; Wang, Y.; Wang, L.; Zhang, B.; Chen, G.; Wan, Q.; Chen, L. Akt3 deletion in mice impairs spatial cognition and hippocampal CA1 long long-term potentiation through downregulation of mTOR. Acta Physiol. 2018, e13167. [CrossRef] [PubMed]

44. Kim, J.-I.; Lee, H.-R.; Sim, S.; Baek, J.; Yu, N.-K.; Choi, J.-H.; Ko, H.-G.; Lee, Y.S.; Park, S.W.; Kwak, C.; et al. $\mathrm{PI} 3 \mathrm{~K} \gamma$ is required for NMDA receptor-dependent long-term depression and behavioral flexibility. Nat. Neurosci. 2011, 14, 1447-1454. [CrossRef] [PubMed]

45. Choi, J.-H.; Park, P.; Baek, G.-C.; Sim, S.-E.; Kang, S.J.; Lee, Y.; Ahn, S.H.; Lim, C.S.; Lee, Y.S.; Collingridge, G.L.; et al. Effects of PI3K $\beta$ overexpression in the hippocampus on synaptic plasticity and spatial learning. Mol. Brain 2014, 7, 78. [CrossRef] [PubMed]

46. Lin, C.H.; Yeh, S.H.; Lin, C.H.; Lu, K.T.; Leu, T.H.; Chang, W.C.; Gean, P.W. A role for the PI-3 kinase signaling pathway in fear conditioning and synaptic plasticity in the amygdala. Neuron 2001, 31, 841-851. [CrossRef]

47. Seitz, C.; Hugle, M.; Cristofanon, S.; Tchoghandjian, A.; Fulda, S. The dual PI3K/mTOR inhibitor NVP-BEZ235 and chloroquine synergize to trigger apoptosis via mitochondrial-lysosomal cross-talk. Int. J. Cancer 2013, 132, 2682-2693. [CrossRef] [PubMed]

48. Liu, Q.; Qiu, J.; Liang, M.; Golinski, J.; van Leyen, K.; Jung, J.E.; You, Z.; Lo, E.H.; Degterev, A.; Whalen, M.J. Akt and mTOR mediate programmed necrosis in neurons. Cell Death Dis. 2014, 5, e1084. [CrossRef] [PubMed]

49. Ribeiro, M.; Rosenstock, T.R.; Oliveira, A.M.; Oliveira, C.R.; Rego, A.C. Insulin and IGF-1 improve mitochondrial function in a PI-3K/Akt-dependent manner and reduce mitochondrial generation of reactive oxygen species in Huntington's disease knock-in striatal cells. Free Radic. Biol. Med. 2014, 74, 129-144. [CrossRef] [PubMed]

50. Kim, D.I.; Lee, K.H.; Gabr, A.A.; Choi, G.E.; Kim, J.S.; Ko, S.H.; Han, H.J. A $\beta$-Induced Drp1 phosphorylation through Akt activation promotes excessive mitochondrial fission leading to neuronal apoptosis. Biochim. Biophys. Acta Mol. Cell Res. 2016, 1863, 2820-2834. [CrossRef] [PubMed]

51. Lim, S.L.; Rodriguez-Ortiz, C.J.; Kitazawa, M. Infection, systemic inflammation, and Alzheimer's disease. Microbes Infect. 2015, 17, 549-556. [CrossRef] [PubMed] 
52. Avila-Muñoz, E.; Arias, C. When astrocytes become harmful: Functional and inflammatory responses that contribute to Alzheimer's disease. Ageing Res. Rev. 2014, 18, 29-40. [CrossRef] [PubMed]

53. Medeiros, R.; LaFerla, F.M. Astrocytes: Conductors of the Alzheimer disease neuroinflammatory symphony. Exp. Neurol. 2013, 239, 133-138. [CrossRef] [PubMed]

54. Heneka, M.T.; O’Banion, M.K.; Terwel, D.; Kummer, M.P. Neuroinflammatory processes in Alzheimer's disease. J. Neural Transm. 2010, 117, 919-947. [CrossRef] [PubMed]

55. Olson, L.; Humpel, C. Growth factors and cytokines/chemokines as surrogate biomarkers in cerebrospinal fluid and blood for diagnosing Alzheimer's disease and mild cognitive impairment. Exp. Gerontol. 2010, 45, 41-46. [CrossRef] [PubMed]

56. McGeer, E.G.; McGeer, P.L. Inflammatory processes in Alzheimer's disease. Prog. Neuro-Psychopharmacol. Biol. Psychiatry 2003, 27, 741-749. [CrossRef]

57. Troutman, T.D.; Bazan, J.F.; Pasare, C. Toll-like receptors, signaling adapters and regulation of the pro-inflammatory response by PI3K. Cell Cycle 2012, 11, 3559-3567. [CrossRef] [PubMed]

58. Aksoy, E.; Taboubi, S.; Torres, D.; Delbauve, S.; Hachani, A.; Whitehead, M.A.; Pearce, W.P.; Berenjeno, I.M.; Nock, G.; Filloux, A.; et al. The p1108 isoform of the kinase PI(3)K controls the subcellular compartmentalization of TLR4 signaling and protects from endotoxic shock. Nat. Immunol. 2012, 13, 1045-1054. [CrossRef] [PubMed]

59. Deng, Q.; Huttenlocher, A. Leukocyte migration from a fish eye's view. J. Cell Sci. 2012, 125, 3949-3956. [CrossRef] [PubMed]

60. Barberis, L.; Pasquali, C.; Bertschy-Meier, D.; Cuccurullo, A.; Costa, C.; Ambrogio, C.; Vilbois, F.; Chiarle, R.; Wymann, M.; Altruda, F.; et al. Leukocyte transmigration is modulated by chemokine-mediated PI3K $\gamma$-dependent phosphorylation of vimentin. Eur. J. Immunol. 2009, 39, 1136-1146. [CrossRef] [PubMed]

61. Stephens, L.; Milne, L.; Hawkins, P. Moving towards a better understanding of chemotaxis. Curr. Biol. 2008, 18, 485-494. [CrossRef] [PubMed]

62. Ferguson, G.J.; Milne, L.; Kulkarni, S.; Sasaki, T.; Walker, S.; Andrews, S.; Crabbe, T.; Finan, P.; Jones, G.; Jackson, S.; et al. $\mathrm{PI}(3) \mathrm{K} \gamma$ has an important context-dependent role in neutrophil chemokinesis. Nat. Cell Biol. 2007, 9, 86-91. [CrossRef] [PubMed]

63. Smith, D.; Deem, T.; Bruce, A.; Reutershan, J.; Wu, D. Leukocyte phosphoinositide-3 kinase \{gamma\} is required for chemokine-induced, sustained adhesion under flow in vivo. J. Leukoc. Biol. 2006, 80, 1491-1499. [CrossRef] [PubMed]

64. Jones, G.E.; Prigmore, E.; Calvez, R.; Hogan, C.; Dunn, G.A.; Hirsch, E.; Wymann, M.P.; Ridley, A.J. Requirement for PI 3-kinase $\gamma$ in macrophage migration to MCP-1 and CSF-1. Exp. Cell Res. 2003, 290, 120-131. [CrossRef]

65. Hirsch, E.; Katanaev, V.L.; Garlanda, C.; Azzolino, O.; Pirola, L.; Silengo, L.; Sozzani, S.; Mantovani, A.; Altruda, F.; Wymann, M.P. Central role for G protein-coupled phosphoinositide 3-kinase gamma in inflammation. Science 2000, 287, 1049-1053. [CrossRef] [PubMed]

66. Sasaki, T.; Irie-Sasaki, J.; Jones, R.G.; Oliveira-dos-Santos, A.J.; Stanford, W.L.; Bolon, B.; Wakeham, A.; Itie, A.; Bouchard, D.; Kozieradzki, I.; et al. Function of PI3Kgamma in thymocyte development, T cell activation, and neutrophil migration. Science 2000, 287, 1040-1046. [CrossRef] [PubMed]

67. Saponaro, C.; Cianciulli, A.; Calvello, R.; Dragone, T.; Iacobazzi, F.; Panaro, M.A. The PI3K/Akt pathway is required for LPS activation of microglial cells. Immunopharmacol. Immunotoxicol. 2012, 34, 858-865. [CrossRef] [PubMed]

68. Chen, G.; Liu, S.; Pan, R.; Li, G.; Tang, H.; Jiang, M.; Xing, Y.; Jin, F.; Lin, L.; Dong, J. Curcumin Attenuates gp120-Induced Microglial Inflammation by Inhibiting Autophagy via the PI3K Pathway. Cell Mol. Neurobiol. 2018, 38, 1465-1477. [CrossRef] [PubMed]

69. Cianciulli, A.; Calvello, R.; Porro, C.; Trotta, T.; Salvatore, R.; Panaro, M.A. PI3k/Akt signalling pathway plays a crucial role in the anti-inflammatory effects of curcumin in LPS-activated microglia. Int. Immunopharmacol. 2016, 36, 282-290. [CrossRef] [PubMed]

70. Jung, J.-S.; Choi, M.-J.; Lee, Y.Y.; Moon, B.-I.; Park, J.-S.; Kim, H.-S. Suppression of LipopolysaccharideInduced Neuroinflammation by Morin via MAPK, PI3K/Akt, and PKA/HO-1 Signaling Pathway Modulation. J. Agric. Food Chem. 2017, 65, 373-382. [CrossRef] [PubMed] 
71. Kim, W.-K.; Hwang, S.-Y.; Oh, E.-S.; Piao, H.Z.; Kim, K.-W.; Han, I.-O. TGF-beta1 represses activation and resultant death of microglia via inhibition of phosphatidylinositol 3-kinase activity. J. Immunol. 2004, 172, 7015-7023. [CrossRef] [PubMed]

72. Zhao, M.; Zhou, A.; Xu, L.; Zhang, X. The role of TLR4-mediated PTEN/PI3K/AKT/NF- $\mathrm{BB}$ signaling pathway in neuroinflammation in hippocampal neurons. Neuroscience 2014, 269, 93-101. [CrossRef] [PubMed]

73. Wang, P.; He, Y.; Li, D.; Han, R.; Liu, G.; Kong, D.; Hao, J. Class I PI3K inhibitor ZSTK474 mediates a shift in microglial/macrophage phenotype and inhibits inflammatory response in mice with cerebral ischemia/reperfusion injury. J. Neuroinflamm. 2016, 13, 192. [CrossRef] [PubMed]

74. Huang, L.; Sherchan, P.; Wang, Y.; Reis, C.; Applegate, R.L.; Tang, J.; Zhang, J.H. Phosphoinositide 3-Kinase Gamma Contributes to Neuroinflammation in a Rat Model of Surgical Brain Injury. J. Neurosci. 2015, 35, 10390-10401. [CrossRef] [PubMed]

75. Mozolewski, P.; Moskot, M.; Jakóbkiewicz-Banecka, J.; Węgrzyn, G.; Bocheńska, K.; Banecki, B.; Gabig-Cimińska, M. Nonsteroidal anti-inflammatory drugs modulate cellular glycosaminoglycan synthesis by affecting EGFR and PI3K signaling pathways. Sci. Rep. 2017, 7, 43154. [CrossRef] [PubMed]

76. Zhou, H.; Liu, W.; Su, Y.; Wei, Z.; Liu, J.; Kolluri, S.K.; Wu, H.; Cao, Y.; Chen, J.; Wu, Y.; et al. NSAID sulindac and its analog bind RXRalpha and inhibit RXRalpha-dependent AKT signaling. Cancer Cell 2010, 17, 560-573. [CrossRef] [PubMed]

77. Stark, D.T.; Bazan, N.G. Neuroprotectin D1 Induces Neuronal Survival and Downregulation of Amyloidogenic Processing in Alzheimer's Disease Cellular Models. Mol. Neurobiol. 2011, 43, 131-138. [CrossRef] [PubMed]

78. Vojtek, A.B.; Taylor, J.; DeRuiter, S.L.; Yu, J.-Y.; Figueroa, C.; Kwok, R.P.; Turner, D.L. Akt regulates basic helix-loop-helix transcription factor-coactivator complex formation and activity during neuronal differentiation. Mol. Cell Biol. 2003, 23, 4417-4427. [CrossRef] [PubMed]

79. Meng, J.; Li, Y.; Camarillo, C.; Yao, Y.; Zhang, Y.; Xu, C.; Jiang, L. The anti-tumor histone deacetylase inhibitor SAHA and the natural flavonoid curcumin exhibit synergistic neuroprotection against amyloid-beta toxicity. PLoS ONE 2014, 9, 1-11. [CrossRef] [PubMed]

80. Mantamadiotis, T. Towards targeting PI3K-dependent regulation of gene expression in brain cancer. Cancers 2017, 9, 60. [CrossRef] [PubMed]

81. Shi, Z.M.; Han, Y.W.; Han, X.H.; Zhang, K.; Chang, Y.N.; Hu, Z.M.; Qi, H.X.; Ting, C.; Zhen, Z.; Hong, W. Upstream regulators and downstream effectors of NF-кB in Alzheimer's disease. J. Neurol Sci. 2016, 366, 127-134. [CrossRef] [PubMed]

82. Chen, Y.L.; Monteith, N.; Law, P.Y.; Loh, H.H. Dynamic association of p300 with the promoter of the G protein-coupled rat delta opioid receptor gene during NGF-induced neuronal differentiation. Biochem. Biophys. Res. Commun. 2010, 396, 294-298. [CrossRef] [PubMed]

83. Chen, Y.L.; Law, P.-Y.; Loh, H.H. NGF/PI3K signaling-mediated epigenetic regulation of delta opioid receptor gene expression. Biochem. Biophys. Res. Commun. 2008, 368, 755-760. [CrossRef] [PubMed]

84. Yamaguchi, A.; Tamatani, M.; Matsuzaki, H.; Namikawa, K.; Kiyama, H.; Vitek, M.P.; Mitsuda, N.; Tohyama, M. Akt Activation Protects Hippocampal Neurons from Apoptosis by Inhibiting Transcriptional Activity of p53. J Biol. Chem. 2001, 276, 5256-5264. [CrossRef] [PubMed]

85. Sanphui, P.; Biswas, S.C. FoxO3a is activated and executes neuron death via Bim in response to $\beta$-amyloid. Cell Death Dis. 2013, 4, e625-12. [CrossRef] [PubMed]

86. Leng, Y.; Wang, Z.; Tsai, L.K.; Leeds, P.; Fessler, E.B.; Wang, J.; Chuang, D.M. FGF-21, a novel metabolic regulator, has a robust neuroprotective role and is markedly elevated in neurons by mood stabilizers. Mol. Psychiatry 2015, 20, 215-223. [CrossRef] [PubMed]

87. Walker, M.P.; LaFerla, F.M.; Oddo, S.S.; Brewer, G.J. Reversible epigenetic histone modifications and Bdnf expression in neurons with aging and from a mouse model of Alzheimer's disease. Age (Omaha) 2013, 35, 519-531. [CrossRef] [PubMed]

88. Narayan, P.J.; Lill, C.; Faull, R.; Curtis, M.A.; Dragunow, M. Increased acetyl and total histone levels in post-mortem Alzheimer's disease brain. Neurobiol. Dis. 2015, 74, 281-294. [CrossRef] [PubMed]

89. Marques, S.C.F.; Lemos, R.; Ferreiro, E.; Martins, M.; de Mendonça, A.; Santana, I.; Quteiro, T.F.; Pereira, C.M.F. Epigenetic regulation of BACE1 in Alzheimer's disease patients and in transgenic mice. Neuroscience 2012, 220, 256-266. [CrossRef] [PubMed] 
90. Lu, X.; Deng, Y.; Yu, D.; Cao, H.; Wang, L.; Liu, L.; Yu, C.; Zhang, Y.; Guo, X.; Yu, G. Histone acetyltransferase p300 mediates histone acetylation of PS1 and BACE1 in a cellular model of Alzheimer's disease. PLoS ONE 2014, 9, 1-9. [CrossRef] [PubMed]

91. Spangle, J.M.; Roberts, T.M.; Zhao, J.J. The emerging role of PI3K/AKT-mediated epigenetic regulation in cancer. Biochim. Biophys. Acta Rev. Cancer 2017, 1868, 123-131. [CrossRef] [PubMed]

92. Jarome, T.J.; Perez, G.A.; Hauser, R.M.; Hatch, K.M.; Lubin, F.D. EZH2 Methyltransferase Activity Controls Pten Expression and mTOR Signaling During Fear Memory Reconsolidation. J. Neurosci. 2018, 38, 7635-7648. [CrossRef] [PubMed]

93. Mastroeni, D.; Delvaux, E.; Nolz, J.; Tan, Y.; Grover, A.; Oddo, S.; Coleman, P.D. Aberrant intracellular localization of H3k4me3 demonstrates an early epigenetic phenomenon in Alzheimer's disease. Neurobiol. Aging 2015, 36, 3121-3129. [CrossRef] [PubMed]

94. Zhang, X.; He, X.; Li, Q.; Kong, X.; Ou, Z.; Zhang, L.; Gong, Z.; Long, D.; Li, J.; Zhang, M.; et al. PI3K/AKT/mTOR Signaling Mediates Valproic Acid-Induced Neuronal Differentiation of Neural Stem Cells through Epigenetic Modifications. Stem Cell Rep. 2017, 8, 1256-1269. [CrossRef] [PubMed]

95. Griñán-Ferré, C.; Sarroca, S.; Ivanova, A.; Puigoriol-Illamola, D.; Aguado, F.; Camins, A.; Coral, S.; Pallas, M. Epigenetic mechanisms underlying cognitive impairment and Alzheimer disease hallmarks in 5XFAD mice. Aging (Albany NY) 2016, 8, 664-684. [CrossRef] [PubMed]

96. Chouliaras, L.; Mastroeni, D.; Delvaux, E.; Grover, A.; Kenis, G.; Hof, P.R.; Steinbusch, H.W.M.; Coleman, P.D.; Rutten, B.P.F.; Van den Hove, D.L.A. Consistent decrease in global DNA methylation and hydroxymethylation in the hippocampus of Alzheimer's disease patients. Neurobiol. Aging 2013, 34, 2091-2099. [CrossRef] [PubMed]

97. Watson, C.T.; Roussos, P.; Garg, P.; Ho, D.J.; Azam, N.; Katsel, P.L.; Haroutunian, V.; Sharp, A.J. Genome-wide12 DNA methylation profiling in the superior temporal gyrus reveals epigenetic signatures associated with Alzheimer's disease. Genome Med. 2016, 8, 1-14. [CrossRef] [PubMed]

98. Nagata, T.; Kobayashi, N.; Ishii, J.; Shinagawa, S.; Nakayama, R.; Shibata, N.; Kueban, B.; Ohnuma, T.; Kondo, K.; Arai, H.; et al. Association between DNA methylation of the BDNF promoter region and clinical presentation in Alzheimer's disease. Dement Geriatr. Cogn. Dis. Extra 2015, 5, 64-73. [CrossRef] [PubMed]

99. Posor, Y.; Eichhorn-Gruenig, M.; Puchkov, D.; Schöneberg, J.; Ullrich, A.; Lampe, A.; Muller, R.; Zarbakhsh, S.; Gulluni, F.; Hirsch, E.; et al. Spatiotemporal control of endocytosis by phosphatidylinositol-3,4-bisphosphate. Nature 2013, 499, 233-237. [CrossRef] [PubMed]

100. Arcaro, A.; Zvelebil, M.J.; Wallasch, C.; Ullrich, A.; Waterfield, M.D.; Domin, J. Class II phosphoinositide 3-kinases are downstream targets of activated polypeptide growth factor receptors. Mol. Cell Biol. 2000, 20, 3817-3830. [CrossRef] [PubMed]

101. Wu, K.; Yang, L.; Chen, J.; Zhao, H.; Wang, J.; Xu, S.; Huang, Z. miR-362-5p inhibits proliferation and migration of neuroblastoma cells by targeting phosphatidylinositol 3-kinase-C2 $\beta$. FEBS Lett. 2015, 589, 1911-1919. [CrossRef] [PubMed]

102. Garcia, M.D.; Formoso, K.; Aparicio, G.I.; Frasch, A.C.C.; Scorticati, C. The Membrane Glycoprotein M6a Endocytic/Recycling Pathway Involves Clathrin-Mediated Endocytosis and Affects Neuronal Synapses. Front. Mol. Neurosci. 2017, 10, 296. [CrossRef] [PubMed]

103. Vagnozzi, A.N.; Praticò, D. Endosomal sorting and traf fi cking, the retromer complex and neurodegeneration. Mol. Psychiatry 2018. [CrossRef] [PubMed]

104. Wu, J.; Petralia, R.S.; Kurushima, H.; Patel, H.; Jung, M.; Volk, L.; Chowdhury, S.; Shepherd, J.D.; Dehoff, M.; Li, Y.; et al. Arc/Arg3. 1 Regulates an Endosomal Pathway Essential for Activity-Dependent b-Amyloid Generation. Cell 2011, 147, 615-628. [CrossRef] [PubMed]

105. Domin, J.; Gaidarov, I.; Smith, M.E.; Keen, J.H.; Waterfield, M.D. The class II phosphoinositide 3-kinase PI3K-C2alpha is concentrated in the trans-Golgi network and present in clathrin-coated vesicles. J. Biol. Chem. 2000, 275, 11943-11950. [CrossRef] [PubMed]

106. Gaidarov, I.; Smith, M.E.; Domin, J.; Keen, J.H. The class II phosphoinositide 3-kinase C2alpha is activated by clathrin and regulates clathrin-mediated membrane trafficking. Mol. Cell 2001, 7, 443-449. [CrossRef]

107. Meunier, F.A.; Osborne, S.L.; Hammond, G.R.V.; Cooke, F.T.; Parker, P.J.; Domin, J.; Schiavo, G. Phosphatidylinositol 3-Kinase C2 $\alpha$ Is Essential for ATP-dependent Priming of Neurosecretory Granule Exocytosis. Mol. Biol. Cell 2005, 16, 4841-4851. [CrossRef] [PubMed] 
108. Shiwarski, D.J.; Darr, M.; Telmer, C.A.; Bruchez, M.P.; Puthenveedu, M.A. PI3K class II $\alpha$ regulates $\delta$-opioid receptor export from the trans-Golgi network. Mol. Biol. Cell 2017, 28, 2202-2219. [CrossRef] [PubMed]

109. Hauswirth, A.G.; Ford, K.J.; Wang, T.; Fetter, R.D.; Tong, A.; Davis, G.W. A postsynaptic PI3K-cII dependent signaling controller for presynaptic homeostatic plasticity. Elife 2018, 7, e31535. [CrossRef] [PubMed]

110. Byfield, M.P.; Murray, J.T.; Backer, J.M. hVps34 Is a Nutrient-regulated Lipid Kinase Required for Activation of p70 S6 Kinase. J. Biol. Chem. 2005, 280, 33076-33082. [CrossRef] [PubMed]

111. Zhou, F.; Yang, Y.; Xing, D. Bcl-2 and Bcl-xL play important roles in the crosstalk between autophagy and apoptosis. FEBS J. 2011, 278, 403-413. [CrossRef] [PubMed]

112. Komatsu, M.; Ichimura, Y. MBSJ MCC Young Scientist Award 2009 REVIEW: Selective autophagy regulates various cellular functions. Genes Cells 2010, 15, 923-933. [CrossRef] [PubMed]

113. Gerónimo-Olvera, C.; Montiel, T.; Rincon-Heredia, R.; Castro-Obregón, S.; Massieu, L. Autophagy fails to prevent glucose deprivation/glucose reintroduction-induced neuronal death due to calpain-mediated lysosomal dysfunction in cortical neurons. Cell Death Dis. 2017, 8, e2911. [CrossRef] [PubMed]

114. Issman-Zecharya, N.; Schuldiner, O. The PI3K Class III Complex Promotes Axon Pruning by Downregulating a Ptc-Derived Signal via Endosome-Lysosomal Degradation. Dev. Cell 2014, 31, 461-473. [CrossRef] [PubMed]

(C) 2018 by the authors. Licensee MDPI, Basel, Switzerland. This article is an open access article distributed under the terms and conditions of the Creative Commons Attribution (CC BY) license (http://creativecommons.org/licenses/by/4.0/). 